Berichte der Deutschen Botanischen Gesellschaft

Journal of the German Botanical Society
Editors

Ulrich Lüttge, Darmstadt (Editor-in-Chief)

Eberhard Schnepf, Heidelberg

$$
\text { (Co-Editor) }
$$

André Läuchli, Davis, California (Editor)

Toshiyuki Nagata, Tokyo (Editor)

\author{
Associate Editors \\ E. Beck, Bayreuth \\ H.-D. Behnke, Heidelberg \\ A. J. E. van Bel, Utrecht \\ F.-W. Bentrup, Salzburg \\ T. E. Boller, Basel \\ H. Bothe, Köln \\ A. Brennicke, Berlin \\ D. Cosgrove, University Park/PA \\ S. Delrot, Poitiers \\ T. J. Flowers, Falmer, Brighton \\ A. D. M. Glass, Vancouver \\ G. K. Gottsberger, Ulm \\ P. Gräber, Stuttgart \\ H. Griffiths, Newcastle upon Tyne \\ R. Herrmann, München \\ R. L. Jefferies, Toronto \\ J. W. Kadereit, Mainz \\ H. Kauss, Kaiserslautern \\ M. Kluge, Darmstadt \\ P. Leins, Heidelberg \\ H. K. Lichtenthaler, Karlsruhe \\ M. Luckner, Halle \\ P. Matile, Zürich \\ E. Medina, Caracas \\ M. Melkonian, Köln \\ I. de Michelis, Genova \\ W. Morawetz, Wien \\ F. Oberwinkler, Tübingen \\ C. B. Osmond. Canberra \\ B. Parthier, Halle \\ J. B. Passioura, Canberra \\ J. A. Raven, Dundee \\ P. H. Raven, St. Louis/MO \\ D. G. Robinson, Göttingen \\ F. E. Round, Bristol \\ R. Scheibe, Osnabrück \\ H. Schnabl, Bonn \\ H. Senger, Marburg \\ J. A. C. Smith, Oxford \\ L. Taiz, Santa Cruz/CA \\ I. P. Ting, Riverside/CA \\ A. J. Trewavas, Edinburgh \\ E. Weiler, Bochum \\ L. Willmitzer, Berlin \\ O. Wilmanns, Freiburg \\ 408 Figures \\ 67 Tables
}

\section{Georg Thieme Verlag}

Rüdigerstraße 14

D-70469 Stuttgart

Postfach 301120

D-70451 Stuttgart

Thieme Medical Publishers, Inc.

381 Park Avenue South

New York, NY 10016 
No. 1 (February 1994)= Page $1-60$

No. 2 (April 1994) = Page 61-110

No.3 (June 1994) = Page 111-182

No. 4 (August 1994) = Page 187 -270

No. 5 (October 1994) = Page 271-368

No. 6 (December 1994) = Page $369-472$

251 Structural Aspects of the Lichen-Rock Interface using Back-scattered Electron Imaging

C. Ascaso and J. Wierzchos

313 Regulation of NADP-Dependent Glyceraldehyde 3Phosphate Dehydrogenase Activity in Spinach Chloroplasts

Elisabeth Baalmann, J. E. Backhausen, C. Kitzmann, and Renate Scheibe

342 Quantification of the Daily Cytokinin Transport from the Root to the Shoot of Urtica dioica L.

E. Beck and B. M. Wagner

3 Sieve-Element Plastids, Nuclear Crystals and Phloem Proteins in the Zingiberales

H.-D. Behnke

422 Cyanobacteria of Rocks and Soils of the Orinoco Lowlands and the Guayana Uplands, Venezuala

B. Büdel, U. Lüttge, R. Stelzer, O. Huber, and E. Medina

271 Pre-adaptation of Arctic Plants to Climate Change R. M. M. Crawford and R. J. Abbott

18 Polyamines and Morphogenesis - Effects of Methylglyoxal-bis(guanylhydrazone)

Annie Féray, A. Hourmant, M. Penot, J. Caroff, and Christine Cann-Moisan

46 Diurnal Pattern of Transpiration, Water Uptake and Water Budget of Succulents with Different $\mathrm{CO}_{2}$ Fixation Pathways

Barbara M.-T. Flach and B. M. Eiler

300 Elicitation of 2,3-Dihydroxybenzoic Acid and Ajmalicine in a Catharanthus roseus Suspension Culture K. T. Frankmann and H. Kauss

12 Chloroplast Development in Rye Coleoptiles M. Fröhlich and U. Kutschera

66 Tidal Dependence of Photoinhibition of Photosynthesis in Marine Macrophytes of the South China Sea D. Hanelt, J. Li, and W. Nultsch

383 How to Evolve a Complex Plastid? - A Hypothesis M. M. Häuber, S. B. Müller, V. Speth, and U.-G. Maier

407 Expression of Polarity during early Development of Microspore-derived and Zygotic Embryos of Brassica napus L. cv. Topas

B. Hause, W. L. H. van Veenendaal, G. Hause, and A. A. M. van Lammeren
333 Intracellular Localization of Jasmonate-Induced Proteins in Barley Leaves

Bettina Hause, Uta zur Nieden, J. Lehmann, C. Wasternack, and B. Parthier

440 Influence of Drought, Rain and Artificial Irrigation on Photosynthesis, Gas Exchange and Water Relations of the Fynbos Plant Protea acaulos (L.) Reich at the End of the Dry Season

Margaretha Herppich, W. B. Herppich, and D. J. von Willert

468 Tissue- and Cell-Specific Distribution of Connexin 32and Connexin 26-related Proteins from Vicia faba $\mathrm{L}$.

Martina Janßen, Carola Hunte, Kirsten Leineweber, Mona Knop, H. Cramer, O. Traub, and Margot Schulz

81 Imaging the $\mathrm{K}, \mathrm{Mg}, \mathrm{Na}$ and $\mathrm{Ca}$ Distributions in Flax Seeds using SIMS Microscopy

A. Jauneau, C. Ripoll, Marie-Claire Verdus, F. Lefebvre, M. Demarty, and M. Thellier

191 Purification and Characterization of Oxopantoyl Lactone Reductase from Higher Plants: Role in Pantothenate Synthesis

J. H. Julliard

369 Molecules and Morphology, Phylogenetics and Genetics

J. W. Kadereit

24 Touch- and Methyl Jasmonate-induced Lignification in Tendrils of Bryonia dioica Jacq.

Isolde Kaiser, J. Engelberth, Beate Groth, and E. W. Weiler

54 Seasonal Changes in the Cambium of Trees. I. Sucrose Content in Thuja occidentalis

Doris Krabel, Monique Bodson, and W. Eschrich

387 Chronology of Phytoparasitic Fungi Introduced to Germany and Adjacent Countries

H. Kreisel and M. Scholler

230 Blue, Green and Red Fluorescence Signatures and Images of Tobacco Leaves

M. Lang, H. K. Lichtenthaler, Malgorzata Sowinska, P. Summ, and Francine Heisel

279 Field Measurements of Water Relations and $\mathrm{CO}_{2} \mathrm{Ex}-$ change of the Tropical, Cyanobacterial Basidiolichen Dictyonema glabratum in a Panamanian Rainforest

O. L. Lange, B. Büdel, H. Zellner, G. Zotz, and A. Meyer

306 Functional Analysis of the N-Terminal Prepeptides of Watermelon Mitochondrial and Glyoxysomal Malate Dehydrogenases

M. Lehnerer, I. Keizer-Gunnik, M. Veenhuis, and Christine Gietl 
90 Displacement and Return Movement of Chloroplasts in the Marine Dinophyte Pyrocystis noctiluca. Experiments with Optical Tweezers

G. Leitz, K. O. Greulich, and E. Schnepf

393 Chemistry, Anatomy and Morphology of Foliicolous Species of Fellhanera and Badimia (Lichenized Ascomycotina: Lecanorales)

R. Lücking, H. T. Lumbsch, and J. A. Elix

30 The Joint Occurrence of Chloroxanthones in Southern Hemisphere Lecanora Species (Ascomycotina; Lecanoraceae)

H. T. Lumbsch, G. B. Feige, and J. A. Elix

187 Editorial

U. Lüttge

1 Editorial

U. Lüttge and E. Schnepf

451 Effect of Extracellular $\mathrm{Ca}^{2+}$ and $\mathrm{Ca}^{2+}$-Antagonists on the Movement and Chemoorientation of Male Gametes of Ectocarpus siliculosus (Phaeophyceae)

\section{Maier and M. Calenberg}

321 Visualization by Freeze-Fracture Electron Microscopy of Intramembraneous Particles corresponding to the Tonoplast $\mathrm{H}^{+}$-Pyrophosphatase and $\mathrm{H}^{+}$-ATPase of Kalanchö̈ daigremontiana Hamet et Perrier de la Bâthie

J.-B. Mariaux, Andrea Becker, Inge Kemna, R. Ratajczak, Elke Fischer-Schliebs, D. Kramer, U. Lüttge, and G. Marigo

95 Organ- and Tissue-specific Biosynthesis of Flavonoids in Seedlings of Oenolhera odorala (Onagraceae)

\section{G. Neumann and B. Schwemmle}

263 Fish Poisoning Plants in Africa

H. D. Neuwinger

61 Acropetal Water Transport in Submerged Plants o. Pedersen

111 Editorial

\section{A. Pirson}

201 The Non-Ionic Detergent Brij 58 Conserves the Structure of the Tonoplast H+-ATPase of Mesembryanthemum crystallinum L. During Solubilization and Partial Purification

R. Ratajczak

103 A Note on the Evolution of the Stamens in the Laurales, with Emphasis on the Lauraceae

\section{J. G. Rohwer}

402 Coloured Pollen in Cactaceae: a Mimetic Adaptation to Hummingbird-Pollination?

Marie-Jeanette Rose and W. Barthlott
$349 \mathrm{~K}^{+}$Gradients in the Pulvinus of Phaseolus coccineus during Leaf Movement

W. A. Ruge and R. Hampp

432 Physical Interactions of Two Rhizomorph-forming Lichens with their Rock Substrate

W. B. Sanders, Carmen Ascaso, and J. Wierzchos

113 SAG-Sammlung von Algenkulturen at the University of Göttingen Catalogue of Strains 1994

U. G. Schlösser

374 A Phagomyxa-like Endoparasite of the Centric Marine Diatom Bellerochea malleus: A Phagotrophic Plasmodiophoromycete

E. Schnepf

328 Phenotypic Adaptation to Elevated Temperatures of Tonoplast Fluidity in the CAM Plant Kalanchoë daigremontiana is Caused by Membrane Proteins

M. Schomburg and M. Kluge

353 The Casparian Strip of Clivia miniata Reg. Roots: Isolation, Fine Structure and Chemical Nature

L. Schreiber, H.-W. Breiner, M. Riederer, M. Düggelin, and R. Guggenheim

362 Source-sink Characteristic of Photoassimilate Transport in Fertile and Sterile Plants of Chara vulgaris L.

C. Schulte, G. O. Kirst, and U. Winter

461 Specific Transport of Inorganic Phosphate and $\mathrm{C}_{3}$-and $\mathrm{C}_{6}$-Sugar-Phosphates across the Envelope Membranes of Tomato (Lycopersicon esculentum) LeafChloroplasts, Tomato Fruit-Chloroplasts and FruitChromoplasts

Danja Schünemann and Sieglinde Borchert

36 Geosiphon pyriforme, an Endosymbiotic Association of Fungus and Cyanobacteria; the Spore Structure Resembles that of Arbuscular Mycorrhizal (AM) Fungi

A. Schüßler, D. Mollenhauer, E. Schnepf, and M. Kluge

416 Micromorphological and Phytochemical Research on Teucrium scorodonia and Teucrium siculum from the Italian Flora

0. Servettaz, A. Pinetti, F. Bellesia, and L. Bini Maleci

210 Nuclear and Organelle DNA Replication during Spore Germination in Bryophytes and Equisetum

Carola Thoni and E. Schnepf

73 Paxillus involutus/Pinus sylvestris Mycorrhizae from Heavily Polluted Forest II. Ultrastructural and Cytochemical Observations

\section{K. Turnau, I. Kottke, and J. Dexheimer}

243 Compartmentation of Zinc in Roots and Leaves of the Zinc Hyperaccumulator Thlaspi caerulescens J \& C Presl

M. D. Váquez, Ch. Poschenrieder, J. Barceló, A. J. M. Baker, P. Hatton, and G. H. Cope 
291 Water Relations, $\mathrm{CO}_{2}$ Exchange, Water-use Efficiency and Growth of Welwitschia mirabilis Hook. fil. in three Contrasting Habitats of the Namib Desert

D. J. von Willerrt and Ute Wagner-Douglas

257 "Pollen Buds" in Ophiorrhiza (Rubiaceae) and their Role in Pollenkitt Release

Martina Weber and A. Igersheim

237 The Use of DNA Fingerprinting in Ecological Studies of Phragmites australis (Cav.) Trin. ex Steudel

A. Zeidler, S. Schneider, C. Jung, A. E. Melchinger, and $P$. Dittrich

218 High Molecular Weight Organic Compounds in the Xylem Sap of Mangroves: Implications for LongDistance Water Transport

U. Zimmermann, J. J. Zhu, F. Meinzer, G. Goldstein, H. Schneider, G. Zimmermann, R. Benkert, F. Thürmer, P. Melcher, D. Webb, and A. Haase
2 List of reviewers 1992-1993

A 1 Mitteilungen des Vorstandes der DBG

A 3 Mitgliederliste

A17 Mitteilungen des Vorstandes der DBG

A19 Mitteilungen des Vorstandes der DBG

A21 Mitteilungen des Vorstandes der DBG 


\title{
Geosiphon pyriforme, an Endosymbiotic Association of Fungus and Cyanobacteria: the Spore Structure Resembles that of Arbuscular Mycorrhizal (AM) Fungi
}

\author{
A. Schüßler ${ }^{1.3}$, D. Mollenhauer ${ }^{2}$, E. Schnepf $^{1}$, and M. Kluge ${ }^{3}$ \\ ${ }^{1}$ Zellenlehre, Universität Heidelberg, FRG \\ ${ }^{2}$ Forschungsinstitut Senckenberg, Frankfurt a. M., FRG \\ ${ }^{3}$ Institut für Botanik, Technische Hochschule Darmstadt, FRG
}

Received: August 13, 1993; Accepted: December 1, 1993

\section{Abstract}

The zygomycete Geosiphon pyriforme is the only known endocyanosis of a fungus. The Nostoc spp. filaments are included in photosynthetically active and nitrogen fixing, multinucleated bladders, which grow on the soil surface. The spores of the fungus are white or slightly brownish. They are about $250 \mu \mathrm{m}$ in diameter and develop singly on hyphal ends or, less frequently, intercalarly. The wall of the spores consists of a thin innermost layer, a laminated inner layer with a thickness of about $10-13 \mu \mathrm{m}$, and an evanescent outer layer. The laminated layer is composed of helicoidally arranged microfibrils, and is separated from the evanescent outer layer by a thin electron-dense sublayer. Polarisation microscopy indicates the occurrence of chitin. Shape and wall ultrastructure of the Geosiphon spores and their cytoplasm resemble that of Glomus spores, but are different from that of other genera of the Glomales and Endogonales. Germination occurs by a single thick hyphal outgrowth directly through the spore wall. Like various AM forming fungi, Geosiphon pyriforme contains endocytic bacteria-like organisms, which are not surrounded by a host membrane. Our observations indicate that Geosiphon is a potential AM fungus.

\section{Key words}

Geosiphon pyriforme, endocyanosis, taxonomy, AM fungi, Glomus.

\section{Abbreviations and Symbols}

AM: $\quad$ Arbuscular mycorrhiza

BLO: bacterium like organism

SG: $\quad$ structured globule

\section{Introduction}

Geosiphon pyriforme is the only known symbiosis of a fungus with endosymbiotic cyanobacteria. This consortium was first recognised by von Wettstein (1915), who described it as a siphonal alga, but also suggested the presence of chitin. Knapp (1933) recognised Geosiphon as a fungus with endosymbiotic cyanobacteria and described it as an intracellular phycomycetal lichen. Today it is clear that the fungal partner is a zygomycete, and the cyanobacteria usually Nostoc punctiforme, but other Nostoc species are also able to take part in this symbiosis (Kluge et al., 1993).

The fungus lives together with Nostoc on the surface and in the uppermost layer of damp, loamy, and nutrient-deficient soils, together with some typical bryophytes in a synusia classified under the community of subatlantic dwarf plants of the Centunculo-Anthocerotetum W. Koch 1926 (Mollenhauer, 1988, 1992). The mycelium consists of syncytial hyphae (diameter $2-8 \mu \mathrm{m}$ ), with septa in senescing or dead hyphae, and may give rise to white to slightly brownish spores with a diameter of about $250 \mu \mathrm{m}$. The symbiotic consortium develops by the endocytosis of Nostoc filaments through a hyphal tip and the formation of a multinucleated, siphonal bladder with a length of up to more than $1 \mathrm{~mm}$ (Knapp, 1933; Mollenhauer, 1988, 1992). During the growth of the bladder, the symbiotic Nostoc cells multiply and increase 10 -fold in volume, compared with the free-living ones. Heterocysts are formed within the bladders in a similar relation to the vegetative cells in free-living Nostoc. The apical two thirds of the mature bladders contain the Nostoc filaments, which are located in a single, sack-formed, peripheral compartment, and many centrally located vacuoles. Fungal cytoplasm in the basal portion contains many lipid droplets, but no cyanobacteria (Kluge et al., 1993).

The biology of Geosiphon pyriforme has been reviewed by Mollenhauer $(1988,1992)$ and Kluge et al. (1993), the ultrastructure was investigated by Schnepf (1964). The latter study contributed substantially to the formulation of Schnepf's theorem of compartmentation of the eucaryotic cell and provided strong arguments in favour of the endosymbiosis theory of cell evolution. Since it is possible to culture Geosiphon pyriforme in the laboratory (Mollenhauer and Mollenhauer, 1988), it could be 
shown that the bladders are photosynthetically active (Kluge et al., 1991) and fix $\mathrm{N}_{2}$ (Kluge et al., 1992).

The fungal partner of the Geosiphon symbiosis forms big, globose spores which are filled with reserve substances (Knapp, 1933). We investigate the shape and ultrastructure of these spores in order to explore the systematic position of the fungus, which is currently uncertain. It turned out that they resemble those of the AM forming genus Glomus (Glomales, Zygomycetes). The validity of the spore shape as a character for taxonomic classification was recently confirmed by small subunit (SSU) rRNA sequence analysis (Simon et al., 1993).

\section{Materials and Methods}

Cultures: Geosiphon pyriforme was cultured on soil of its natural habitat as described by Mollenhauer and Mollenhauer (1988). The spores were harvested from 5-6 months old cultures out of the upper soil layer and germinated in Petri dishes. The germination medium was composed of $0.5 \mathrm{mM} \mathrm{Ca}\left(\mathrm{NO}_{3}\right)_{2}$, $0.5 \mathrm{mM} \mathrm{CaSO}_{4}, 0.5 \mathrm{mM} \mathrm{MgSO}_{4}, 1 \mathrm{mM} \mathrm{NaCl}, 1 \mathrm{mM} \mathrm{KCl}, 10 \mu \mathrm{M}$ $\mathrm{KH}_{2} \mathrm{PO}_{4}, 40 \mu \mathrm{M} \mathrm{H}_{3} \mathrm{BO}_{3}, 2 \mu \mathrm{M} \mathrm{ZnSO}_{4}, 10 \mu \mathrm{M} \mathrm{MnSO}_{4}, 50 \mu \mathrm{M} \mathrm{FeNa}-$ EDTA, and $0.1 \mu \mathrm{M} \mathrm{Na} \mathrm{NoO}_{4}$. Germination was promoted by adding an axenic Funaria hygrometrica protonema of about $1 \mathrm{~cm}$ in diameter onto the liquid surface (see also Mollenhauer, 1988, 1992). The presence of the moss strongly increased germination of the spores.

Light microscopy: The spores were studied with a ZEISS IM 35 microscope and Normarski optics, either in water or in the water soluble ZEISS W15 embedding medium with a refractive index of $n=1.515$. For fluorescence microscopy we used the following filter combinations: UV-light: $365 \mathrm{~nm}$ excitation, longpass $420 \mathrm{~nm}$ emission; blue light: $450-490 \mathrm{~nm}$ excitation, longpass $520 \mathrm{~nm}$ emission.

Electron microscopy: Conventionally fixed and embedded spores were badly preserved. It was not possible to cut ultrathin sections, because the cytoplasm broke out of the spore wall during trimming or cutting. Better results were achieved by fixation with $2.5 \%$ glutaraldehyde in $0.05 \mathrm{M}$ phosphate buffer ( $\mathrm{pH}$ 7.2 ) and vacuum infiltration ( 4 times for 5 minutes), followed by $20 \mathrm{~h}$ at $4{ }^{\circ} \mathrm{C}$ in the same fixant or with the aid of a microwave oven. Hereby the sample was put into an Eppendorf vial $(1.5 \mathrm{ml})$ filled with $2.5 \%$ glutaraldehyde in $0.05 \mathrm{M}$ phosphate buffer and placed in a cool water bath. It was then transferred into a microwave oven for 3 min at 120 watts. This procedure was repeated 5 times. Changing the water bath kept the fixation temperature below $30^{\circ} \mathrm{C}$. The spores were then left for another $3 \mathrm{~h}$ in the same glutaraldehyde solution. After rinsing they were postfixed for $2 \mathrm{~h}$ with $2 \% \mathrm{OsO}_{4}$ in the same buffer, dehydrated in an acetone series $(10$, $25,50,75,90,100,100 \%$, each step 30 minutes), and infiltrated with a series of Spurr's resin (Spurr, 1969) $(30,50,75,100 \%)$, with $12 \mathrm{~h}$ steps at $50 \%$ and $75 \%$ for a better resin penetration (other steps $1 \mathrm{~h}$ ). They were then twice incubated in $100 \%$ Spurr's resin for $12 \mathrm{~h}$. The samples were cut with a diamond knife on a Reichert-Jung Ultracut. The sections were post-stained with uranyl acetate and lead citrate and examined with a Philips CM 10 or EM 400 at $100 \mathrm{kV}$.

To better visualise the wall microfibrils, some spores were extracted in a saturated aqueous $\mathrm{KOH}$ solution for $3 \mathrm{~h}$ at room temperature after glutaraldehyde fixation (BonfanteFasolo and Vian, 1984). Then they were post-fixed with $\mathrm{OsO}_{4}$ and treated as described before.

\section{Results}

\section{Light microscopy}

Geosiphon pyriforme forms single, white or slightly brownish spores with a diameter of about $250 \mu \mathrm{m}$ (Fig. 2); $80 \%$ of the spores have diameters between 220 and $280 \mu \mathrm{m}$ (Fig. 1). They are formed singly at hyphal ends or, less frequently, intercalarly (Figs. 2 and 14). During germinating a single thick hyphal outgrowth emerges directly from the spore wall. It branches immediately into thinner hyphae (Fig. 3).

The spores contain many lipid droplets of different size and "structured globules" (SGs, diameter $3-6 \mu \mathrm{m})$. The latter consist of a highly refracting, homogenous outer and a granular interior part (Fig. 6). The SGs show a strong blue fluorescence when excited with UV light (Fig. 8), and a slight green fluorescence when excited with blue light. They swell within a few minutes after they have been released in water by squeezing the spore. The inner granular appearance is then lost and many SGs eventually fuse (Fig. 7). In W15 embedding medium no granular inner structures are seen.

The spore wall consists of three layers (terminology after Bonfante-Fasolo and Vian, 1984): an innermost one, followed by the thick, laminated inner layer, and an evanescent outer one, which is sometimes lost (Figs. 4 and 9). The innermost layer becomes visible when the spore is squeezed (Fig. 4). It then separates from the inner layer and is flexible. The inner layer is generally about $10-13 \mu \mathrm{m}$ thick and rigid. Often it reveals a laminate appearance which is usually more distinct in the outer part, sometimes giving the impression that this inner layer consists of two different portions. The outermost part of the inner layer consists of a highly refracting sublayer. It is especially visible when the outer evanescent layer is absent (Fig. 10). It resists treatment with concentrated $\mathrm{H}_{2} \mathrm{SO}_{4}$ and is whitish autofluorescent at $365 \mathrm{~nm}$ excitation (greenyellow at $450-490 \mathrm{~nm}$ excitation). The innermost layer is also relatively resistant to $\mathrm{H}_{2} \mathrm{SO}_{4}$. The outer, evanescent layer is irregular in appearance and rather dark (Fig. 9). It extends for some micrometers along the subtending hy-

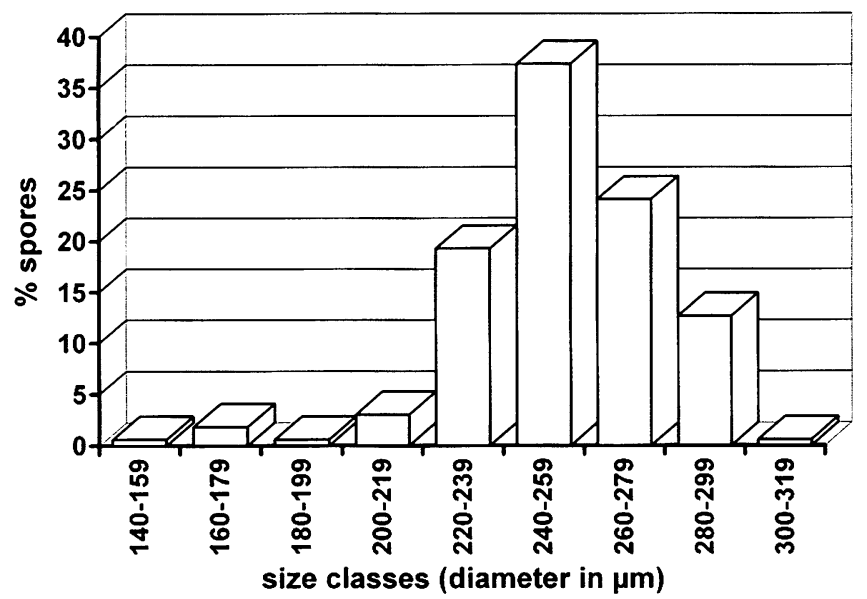

Fig. 1 Size distribution of Geosiphon pyriforme spores (measurement of 166 spores, $M=253.5, S D=23.9$ ). 



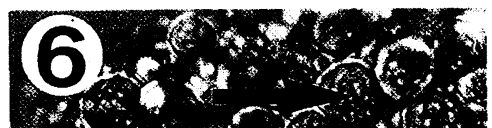
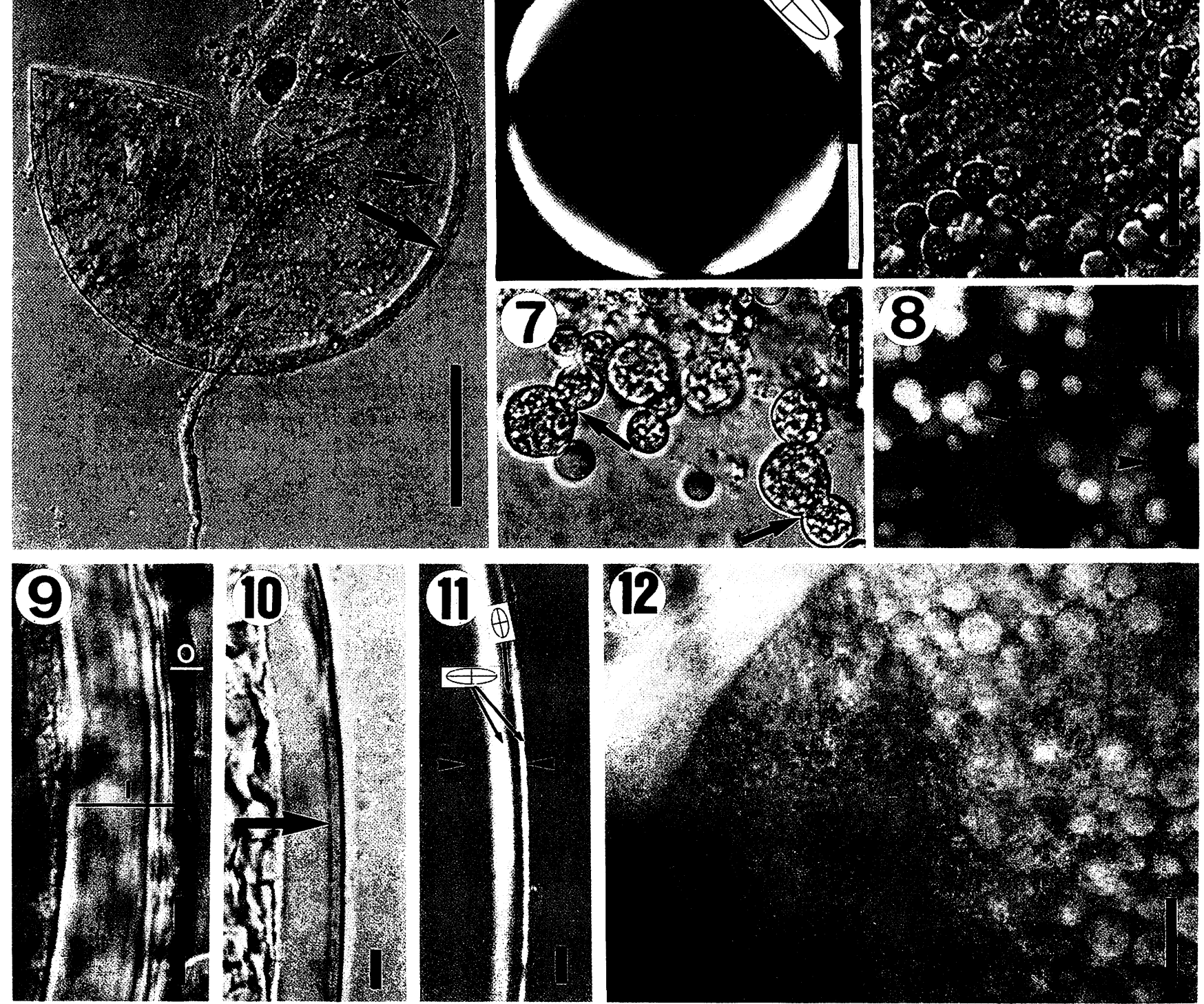

Figs. 2-12 Geosiphon spores, light microscopy. 
pha. This proximal part of the hypha is closed by thin septum-like structures and a long plug comprising the "septa" (Figs. 13 and 14). This plug also continues through the laminated wall of the spore. Inside the hypha it often ends at a thick septum (Fig. 13).

The spore wall is strongly birefringent under the polarising microscope (Fig. 5). In water the relative optical character of all wall layers is positive. In contrast, after incubation with the $\mathrm{W} 15$ medium the relative optical character of the inner layer becomes negative, with the exception of the dark outer sublayer. The birefringence of the inner layer continuously decreases towards the innermost layer (Figs. 10 and 11).

Before germination of the spore, a "cytoplasmic pole", free of SGs and big lipid droplets, develops (Fig. 12). In this region a single thick hyphal outgrowth emerges directly through the spore wall. Germination is distinctly promoted by the presence of Funaria protonemata (germination rate after 3 weeks without Funaria $6 \%$, with Funaria $68 \%$ ).

4 Fig. 2 Toplight photograph of Geosiphon spores, one spore with two subtending hyphae, showing its intercalary formation (arrows). Scale $\mathrm{bar}=1 \mathrm{~mm}$.

Fig. 3 Germinated spore with branched germination hypha. Scale bar $=100 \mu \mathrm{m}$

Fig.4 Mature spore, crushed out: flexible innermost wall layer separated from the inner wall layer (small arrows), inner wall layer (big arrow), and rest of the evanescent wall layer (arrowheads). Scale bar = $100 \mu \mathrm{m}$

Fig. 5 Polarisation microscopic photograph of a spore in water, the relative optical character is shown by an index ellipse. Scale bar $=100 \mu \mathrm{m}$.

Fig. 6 Structured globules (SGS), immediately after crushing out of the spore. Note the homogeneous outer part (arrowheads) and the granular interior (arrow). Scale bar $=10 \mu \mathrm{m}$.

Fig. 7 Liberated SGs after a few minutes in water, they begin to swell, fuse (arrows), and lose their granular appearance. Scale bar $=10 \mu \mathrm{m}$.

Fig. 8 Epifluorescence with UV excitation: the liberated SGs (arrows) are strongly autofluorescent (light blue), the lipid droplets appear as black globules (arrowheads). Scale bar $=10 \mu \mathrm{m}$.

Fig. 9 Part of the spore wall, the outer evanescent wall layer $(0)$ and the inner laminated wall layer $(I)$ are seen, innermost layer not separated from the inner wall. Scale bar $=10 \mu \mathrm{m}$

Fig. 10 Part of a spore wall without evanescent wall in W 15 embedding medium: the highly refracting outer sublayer of the inner wall layer is seen (arrow). Scale bar $=10 \mu \mathrm{m}$.

Fig. 11 Same part as Fig. 10, polarised light with gypsum Red I plate: the region above the dark sublayer retained a weak positive relative optical character, the other parts have a strong negative relative optical character. The birefraction is much stronger in the outer part of the inner wall than in the inner part. The thickness of the spore wall is marked by arrows. Scale bar $=10 \mu \mathrm{m}$.

Fig. 12 Part of the cytoplasmatic pole of a spore just before germination (left side) and storage granules (SGs and lipid droplets) at the right side. Scale bar $=10 \mu \mathrm{m}$.
Outgrowing hyphae allowed confirmation of the identity of the spores. By addition of Nostoc punctiforme new Geosiphon pyriforme bladders were reconstituted (Fig. 15).

\section{Electron microscopy}

The preservation of the cytoplasm within the spore is insufficient in general and varies, depending on the preparation method. Nevertheless, important details can be observed. The main components of spore contents are big and small lipid droplets (diameter up to $15 \mu \mathrm{m}$ ) and the SGs (Figs. 16 and 17). They measure, in general, $4-6 \mu \mathrm{m}$ in diameter, are osmiophilic, and included within a vesicle. The space between the SG and the vesicle membrane is filled with a coarse, flocculent material (Figs. 17 and 18). At high magnification the dense matrix of the SGs is shown to contain relatively electrontranslucent slightly bent rods in paracrystalline arrays. The rods have a diameter of about $6 \mathrm{~nm}$ and are packed hexagonally with a center-to-center spacing of about $8 \mathrm{~nm}$ (Figs. 18-20).
Fig. 13 Subtending hypha: septum-like structures (small arrowheads), thick closing septum (big arrowhead), plug inside the hypha (small arrow) and connection with the spore wall (big arrow). Scale bar = $50 \mu \mathrm{m}$.

Fig. 14 A spore with two subtending hyphae (big arrows), showing its intercalary formation. Inside one hypha the plug is visible (small arrow). Scale bar $=50 \mu \mathrm{m}$.

Fig. 15 A Geosiphon spore (asterisk) with outgrown, highly branched hyphae and many young Geosiphon bladders, containing endosymbiotic Nostoc filaments. Scale bar $=500 \mu \mathrm{m}$.

Fig. 16 Spore in median section with many SGs and lipid droplets; white areas: some storage granules artificially broken. Scale bar $=$ $100 \mu \mathrm{m}$.

Fig. 17 Higher magnification of the spore content with SGs (white asterisk), SG-vesicle membrane (arrow), and lipid droplets (black asterisk). Scale bar $=10 \mu \mathrm{m}$.

Fig. 18 SGs with paracrystalline regions. Scale bar $=1 \mu \mathrm{m}$

Fig. 19 Paracrystalline regions composed of slightly bent rods in hexagonal arrangement. Scale bar $=0.5 \mu \mathrm{m}$.

Fig. 20 Paracrystalline-arranged rods appear hollow (arrowhead). Scale bar $=0.1 \mu \mathrm{m}$. 

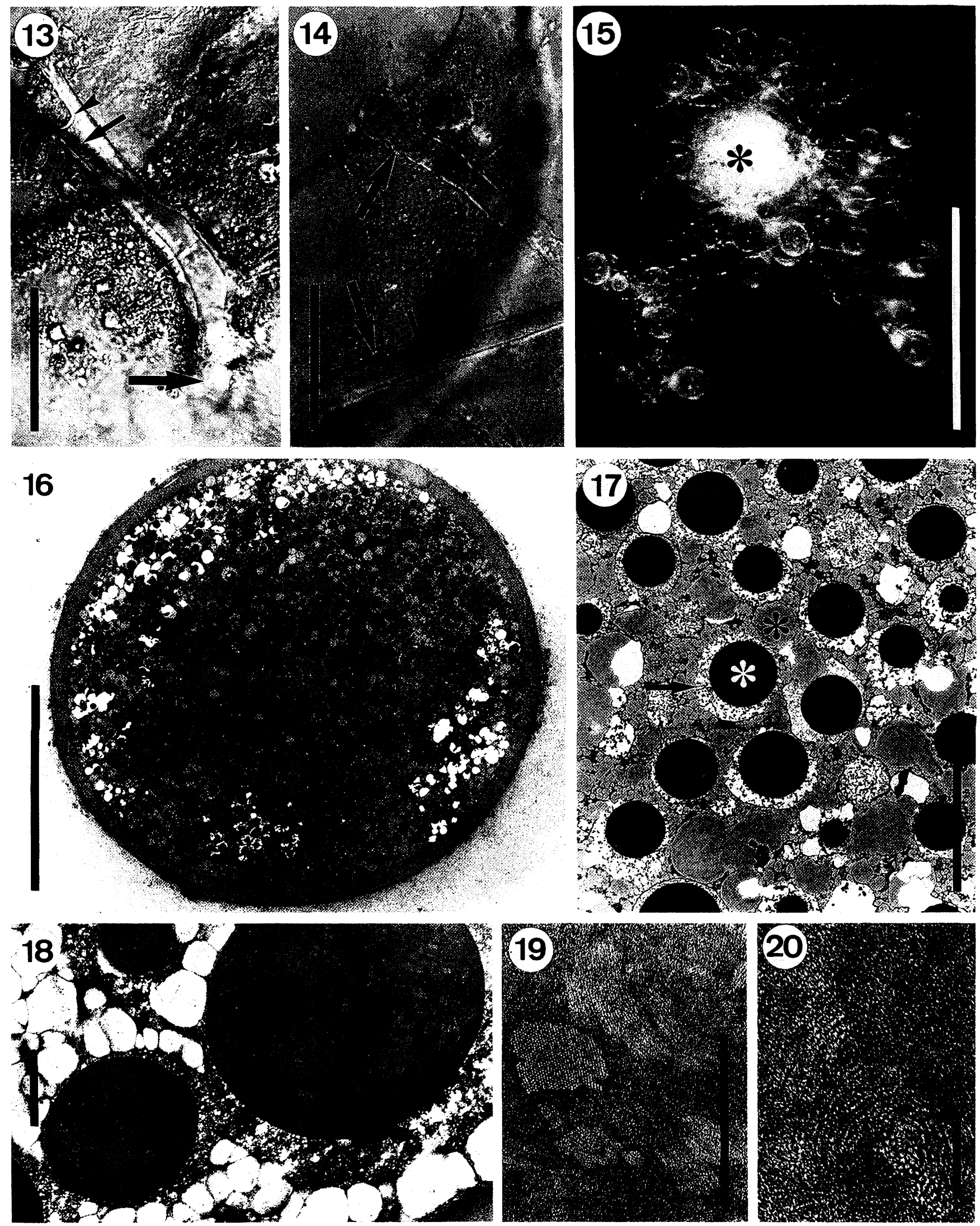

Figs. 13-15 Geosiphon spores, light microscopy.

Figs. 16-20 Geosiphon spores, electron microscopy. 

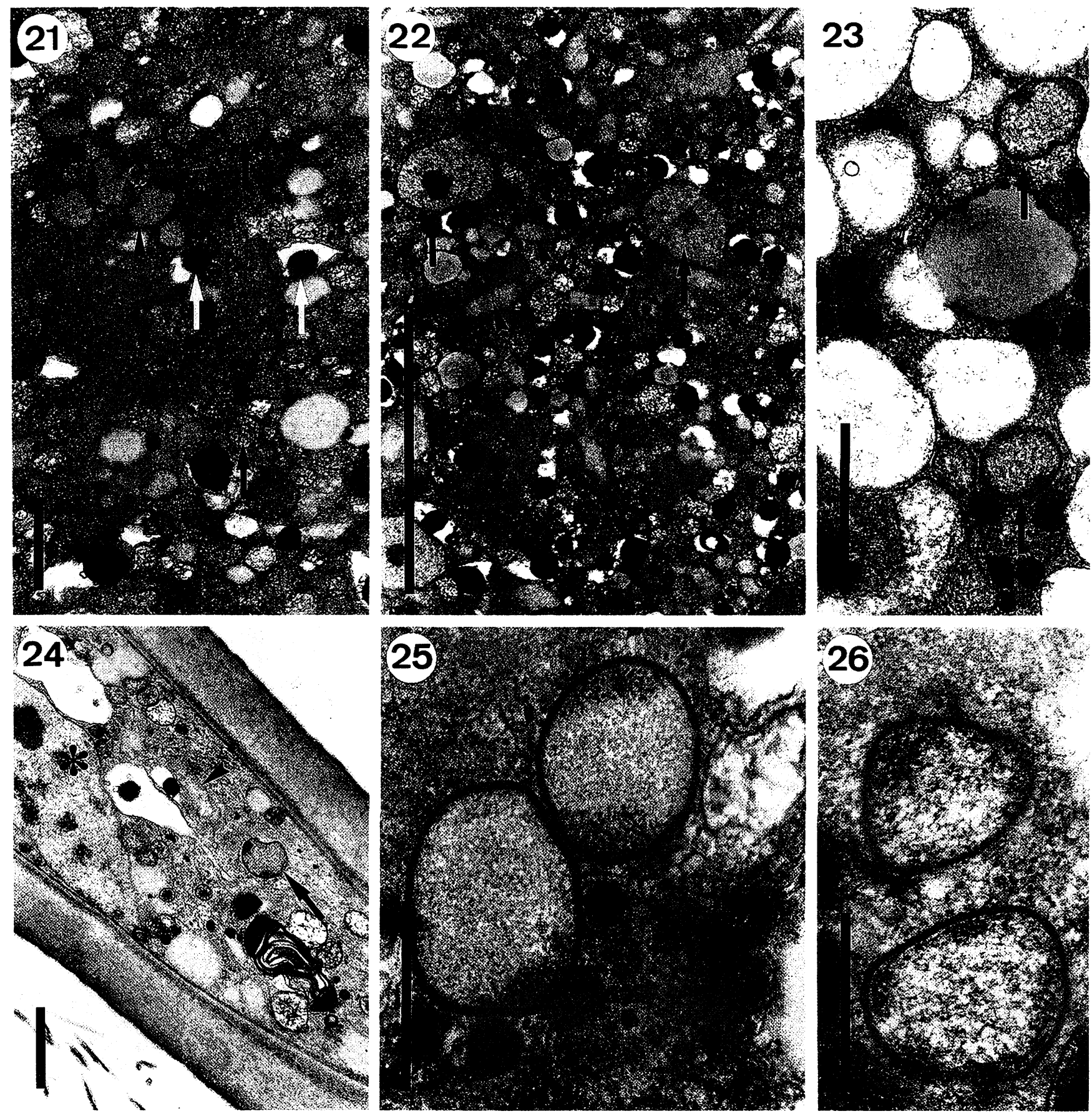

Figs. 21-26 Geosiphon, electron microscopy.

Fig. 21 Part of the cytoplasmic pole of a germinated spore: BLOs (arrowheads), vesicles with flocculent contents (black arrows), and small vacuoles with a highly electron-dense precipitate (white arrows). Scale bar $=1 \mu \mathrm{m}$.

Fig. 22 Same spore as in Fig. 21, part of the cytoplasmic pole, with nuclei (arrow) and mitochondria (arrowheads). Scale bar $=5 \mu \mathrm{m}$.

Fig. 23 BLOs (arrows) within the base of a Nostoc-containing Geosiphon bladder, the upper one with a median constriction. Scale bar $=1 \mu \mathrm{m}$.
Fig. 24 Part of the primary germination hypha of a spore, containing a myelin figure, a BLO (arrow), a nucleus (asterisk), and a mitochondrium (arrowhead), thick cell wall. Scale bar $=1 \mu \mathrm{m}$.

Fig. 25 BLOs in the cytoplasmic pole of a spore. Scale bar $=0.5 \mu \mathrm{m}$

Fig. 26 BLOs in the base of a Nostoc-containing bladder. Scale bar = $0.5 \mu \mathrm{m}$. 
The cytoplasmic pole of germinating spores contains, besides nuclei and mitochondria, mainly small lipid droplets, small vacuoles with an electron dense precipitate which does not completely fill the vacuole, and vesicles with coarse, flocculent contents (Figs. 21 and 22). In addition, in the spores (Figs. 21, 23 and 25) as well as in the outgrown hyphae (Fig. 24) and in the bases of the Nostoc-containing bladders (Figs. 23 and 26), bacteria-like organisms (BLOs) are found. They measure about $0.5 \mu \mathrm{m}$ in diameter and are ovoid, frequently with a median constriction (Fig. 23). A surrounding host membrane is lacking. The BLOs have a relatively thick cell wall, covering the plasma membrane. An "outer membrane" is not present. The large ribosome-free central area contains fine fibrils, presumably representing the DNA (Fig. 26).

The inner, laminated wall layer is the most prominent part of the spore wall, as also seen with the light microscope. Its laminated structure is especially distinct in its outer part (Figs. 27 and 28). Suitable sections at high magnification give the impression of a regular, arc-like substructure (Fig. 33), which is due to the helicoidal pattern in the sense of Bonfante-Fasolo et al. (1986) and Vian et al. (1993). This pattern becomes clearer when the cell walls are pre-treated with $\mathrm{KOH}$ (Figs. 29 and 32). At the outside of the inner wall layer, there is an approximately $0.2 \mu \mathrm{m}$ thick, electron dense sublayer (Figs. 27 and 28). The evanescent outer wall layer is relatively electron dense, irregular, and seems to be packed more loosely than the inner wall (Fig. 27).

The innermost wall layer is about $0.4 \mu \mathrm{m}$ thick and delimited against the inner wall layer by a thin electron-dense zone (Figs. 28-31). This wall layer has a laminated substructure which is, however, not visible everywhere (Fig. 30). This substructure is visualised as thin, electron dense lines (Fig. 31).

\section{Discussion}

The results of our studies indicate various similarities between the spores of Geosiphon pyriforme and those of AM fungi, especially some Glomus species. Polarisation microscopy reveals a strong birefringence, as in Glomus spores (Bonfante and Bianciotto, 1994), and a relative optical character of the inner laminated wall layer which is positive in water but negative in the highly refractive W 15 embedding medium. That indicates a chitinlike molecule character. Chitin is shown to be the main component of spore walls of some Glomus species (Bonfante-Fasolo et al., 1986; Weijman and Meuzelaar, 1979). Von Wettstein (1915) reported evidence for chitin on the photosynthetically active Geosiphon bladders. The different positive optical character of the outermost region of the laminated wall layer cannot be explained. It is probable that this layer is the highly refractive portion and comprises the electron-dense outer sublayer. This region also contains the $\mathrm{H}_{2} \mathrm{SO}_{4}$-resistant part of the wall and the autofluorescing portion. These observations fit well to those of Bonfante-Fasolo and Grippiolo (1984), who described the occurrence of a sporopollenin and melanin-containing layer in Glomus epigaeum at the same location (see also Grippiolo and Bonfante-Fasolo, 1984).
Likewise the arrangement of the putative chitinous microfibrils in the Geosiphon spore wall resembles that of Glomus. The laminated inner wall layer of the Geosiphon spores has the same "arched" appearance as in Glomus fasciculatum (Bonfante-Fasolo, 1982; Bonfante-Fasolo and Schubert, 1987), Glomus versiforme (Bonfante-Fasolo and Grippiolo, 1984; Bonfante-Fasolo and Vian, 1984; Bonfante-Fasolo et al., 1986), Glomus macrocarpum and Glomus caledonium (Bonfante-Fasolo and Schubert, 1987). This pattern is due to a helicoidal arrangement (in the sense of Livolant et al., 1978 and Vian et al., 1993), frequently occurring in cell walls which show strong extension during growth. The microfibrils are deposited parallel in sheets and change their orientation continuously from sheet to sheet (see the model published by Bonfante-Fasolo and Grippiolo, 1984; Bonfante-Fasolo et al., 1986). Such a helicoidal organisation was never described for fungal spores except for those of the group of AM fungi (Bonfante and Bianciotto, 1994), and it is not ubiquitous in the genus Glomus (Bonfante-Fasolo and Schubert, 1987; Meier and Charvat, 1992). The spore wall of Geosiphon resembles most that of Glomus versiforme, which also shows the evanescent outer wall layer, the laminated helicoidal organised inner wall layer, and the innermost wall layer with its lamination, caused by the thin electron dense lines. Although Glomus versiforme forms sporocarps, these features indicate a relatively close relationship between these two organisms.

The helicoidal organisation of microfibrils also exists in spores of Gigaspora spp. (Mosse, 1986; Sward, 1981a) and Acaulospora laevis (Mosse, 1970c; Mosse, 1986), but their spore wall structure clearly differs in the succession and organisation of wall layers from that of the genus Glomus (Mosse, 1970b, c; Sward, 1981a, b, c). These differences are seen also light microscopically and serve to determine the different genera and species of the

Fig. 27 Spore wall: outer evanescent wall layer $(O)$, inner laminated wall layer (I), dark sublayer (D), and innermost wall layer (IM). Scale bar $=5 \mu \mathrm{m}$.

Fig. 28 Spore wall with remainder of the outer evanescent wall layer $(O)$. The region containing the dark sublayer (D) and parts of the inner laminated wall layer are encrusted with electron dense material. Also the innermost wall layer (IM) is seen. Scale bar $=5 \mu \mathrm{m}$.

Fig. $29 \mathrm{KOH}$-extracted spore wall. The region with the electron-dense incrustations, seen in Fig. 28, is strongly swollen, the laminations of the inner wall layer (I) and the innermost wall layer (IM) are more distinct. Scale bar $=5 \mu \mathrm{m}$.

Fig. 30 Homogeneous innermost wall layer, same spore as in Fig. 31 Scale bar $=0.5 \mu \mathrm{m}$

Fig.31 Laminated innermost wall layer of the same spore as in Fig. 30. Scale bar $=0.5 \mu \mathrm{m}$.

Fig. 32 Outer part of the laminated wall layer after $\mathrm{KOH}$ extraction, the arc-like appearance of the microfibrils is clearly seen. Scale bar = $1 \mu \mathrm{m}$.

Fig. 33 Part of the laminated wall without pretreatment with $\mathrm{KOH}$, arc-like substructure. Scale bar $=1 \mu \mathrm{m}$. 

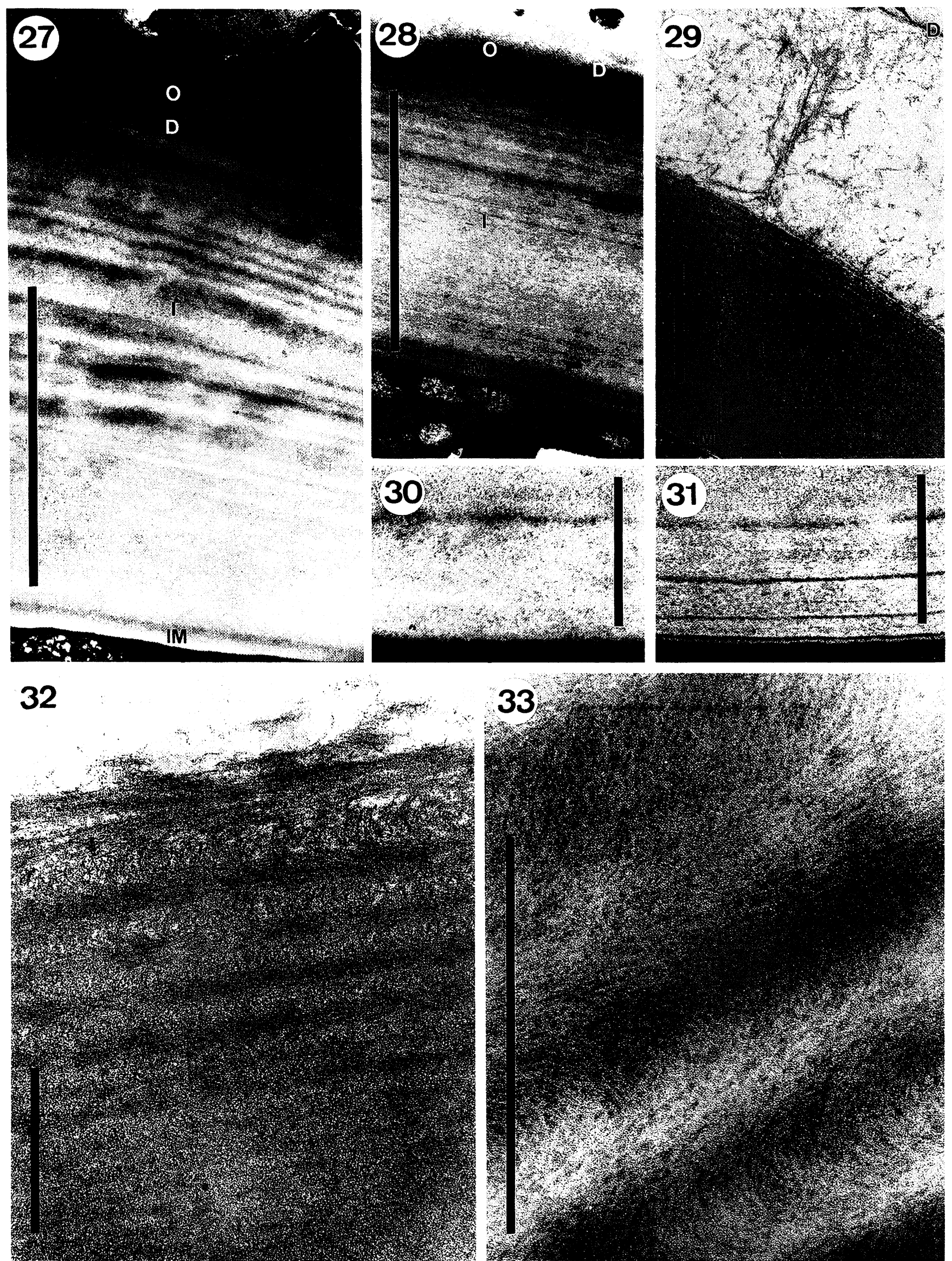

Figs.27-33 Geosiphon spore walls, electron microscopy 
Glomales and Endogonales (Morton, 1988, 1990; Morton and Benny, 1990; Walker, 1983, 1987). The cytoplasmic organisation of the Geosiphon spores and hyphae is similar to that of other Glomus species (Bonfante and Bianciotto, 1994).

During germination of the spores no "germination compartment" is formed, which has been reported for Acaulospora (Mosse, 1970a, c; Mosse, 1986). The germination occurs directly through the spore wall, in contrast to the majority of Glomus species, which germinate through the subtending hypha (Gerdemann and Trappe, 1974). The direct germination is described for Gigaspora margarita (Sward, 1981c), Glomus mossea (Meier and Charvat, 1992), and some other Glomus species. The modes of Glomus spore-germination were recently suggested to be more plastic than has been noted previously (Meier and Charvat, 1992). Also, the formation of "germination compartments" as a character for taxonomic classification has become unclear recently (see Gibson et al., 1987; Mosse, 1986; Walker, 1987).

The formation of the Geosiphon spores is also different from that of Acaulospora and Enteophosphora, which first form a "sporiferous saccule". Gigaspora and Scutellospora show a typical "bulbous suspensor cell" at the subtending hypha. The genus Sclerocystis is obligatory sporocarp-forming and does not form globose spores (Hall, 1987; Morton 1988, Morton and Benny, 1990; Trappe, 1982).

If the spore-characters of Geosiphon are compared with these used for the synoptic keys of Hall (1987), Trappe (1982), the cladogram of Morton (1990), and the revised classification of Morton and Benny (1990), clear evidence for the genus Glomus results.

The bacteria-like organisms (BLOs) are not surrounded by a host membrane. They seem to belong to the Gram-positive bacteria. Their ultrastructure is similar to the BLOs described in other members of the Glomales and Endogonales, like Glomus mosseae (Macdonald et al., 1982; Meier and Charvat, 1992), Gigaspora heterogama, an unidentified "white reticulate" AM fungus (Macdonald et al., 1982), Glomus caledonium (Macdonald and Chandler, 1981), Acaulospora laevis (Mosse, 1970b), Gigaspora margarita (Macdonald et al., 1982; Sward, 1981a, b, c), another unidentified AM fungus (Protzenko, 1974, 1975), Endogone flammicorona (Bonfante-Fasolo and Scannerini, 1977b), Glomus versiforme (Garriock et al., 1989), a member of the Glomus fasciculatus complex (BonfanteFasolo and Scannerini, 1977a; Scannerini and BonfanteFasolo, 1982), and in undetermined members of the Glomales, forming an AM-like association with hepatophytes (Ligrone and Lopes, 1989), anthocerophytes (Ligrone, 1988) and a Lycopodium species (Schmid and Oberwinkler, 1993) (for a review of BLOs in AM fungi see Scannerini and Bonfante-Fasolo, 1992).

We suggest that Geosiphon pyriforme represents a member of the genus Glomus. In consequence the question arises whether Geosiphon is an AM fungus. It is quite possible that it forms AM-like symbioses with mosses, liverworts or hornworts. The induction of hyphal germination by moss exudates (see also Mollenhauer, 1988, 1992; Mollenhauer and Mollenhauer, 1988) supports this possibility. There are different liverworts, a moss (Dicranella staphylina Whitehouse) and an Anthoceros species, living in the natural habitat of Geosiphon (Mollenhauer, 1988, 1992). The hepatics and antherocerotes have been known to form AM-like associations for a long time (Ligrone, 1988; Ligrone and Lopes, 1989; Nemec, 1899; Pocock and Duckett, 1984; Stahl, 1949), and the moss Funaria hygrometrica also forms AM-like associations (Parke and Linderman, 1980).

Molecular biological investigations must show whether Geosiphon is indeed a Glomus spec. Small subunit rRNA sequence data for comparison are available now (Simon et al., 1992; Simon et al., 1993) and did confirm the taxonomic classifications based on spore shape. A method for detecting DNA polymorphism by random amplified polymorphic DNA (RAPD) analysis was reported recently (Wyss and Bonfante, 1993). Geosiphon could then be useful for various further studies on AM fungi.

\section{Acknowledgements}

We are grateful to Prof. Paola Bonfante for helpful discussion, Resi Mollenhauer for the difficult laboratory culture work with Geosiphon, and the Deutsche Forschungsgemeinschaft for support.

\section{References}

Bonfante, P. and Bianciotto, V. - Saprophytic versus symbiotic phase in endomycorrhizal fungi: morphology and cytology. In: Varma, A. and Hock, B., eds., Mycorrhiza: Structure, Function, Molecular Biology and Biotechnology. Springer Verlag, in press, 1994.

Bonfante-Fasolo, P. - Cell wall architectures in a mycorrhizal association as revealed by cryoultramicrotomy. Protoplasma 111 (1982), 113-120.

Bonfante-Fasolo, P. and Grippiolo, R. - Cytochemical and biochemical observations on the cell wall of the spores of Glomus epigaeum. Protoplasma 123 (1984), 140-151.

Bonfante-Fasolo, P. and Scannerini, S. - A cytological study of the vesicular-arbuscular mycorrhiza in Ornithogalum umbellatum $\mathrm{L}$. Allonia 22 (1977a), 5-21.

Bonfante-Fasolo, P. and Scannerini, S. - Cytological observations on the mycorrhiza Endogone flammicorona - Pinus strobus. Allonia 22 (1977b), 23-34

Bonfante-Fasolo, P. and Schubert, A. - Spore wall architecture in Glomus spp. Can. J. Bot. 65 (1987), 539-546.

Bonfante-Fasolo, P. and Vian, B. - Wall texture in the spore of a vesicular-arbuscular mycorrhizal fungus. Protoplasma 120 (1984), $51-60$.

Bonfante-Fasolo, P., Vian, B., and Testa, B. - Ultrastructural localisation of chitin in the cell wall of a fungal spore. Biol. Cell. 57 (1986), 265-270.

Garriock, M. L., Peterson, R. L., and Ackerley, C. A. - Early stages in colonisation of Allium possum (leek) roots by the vesiculararbuscular mycorrhizal fungus, Glomus versiforme. New Phytol. 112 (1989), 85-92.

Gerdemann, J. and Trappe, J.- The Endogonaceae of the pacific northwest. Mycological Memoir no 5. Mycol. Soc. Amer., New York Botanical Garden, New York, 1974.

Gibson, J. L., Benny, G. L., and Kimbrough, J. W. - Gigaspora versus Scutellospora: some ultrastructural observations of azygospore walls. In: Sylvia, D. M., Hung, L. L., and Graham, J. H., eds. Mycorrhizae in the Next Decade, Practical Applications and Research Priorities. p. 313. IFAS, University of Florida, Gainesville, 1987. 
Grippiolo, R. and Bonfante-Fasolo, P. - Sporopollenin and melanin like pigments in the wall of a Glomus spore. G. Bot. Ital. 118 (1984), $88-90$.

Hall, I. R. - Taxonomy and identification of vesicular-arbuscular mycorrhizal fungi. Angew. Bot. 61 (1987), 145-152.

Kluge, M., Mollenhauer, D., and Mollenhauer, R. - Photosynthetic carbon assimilation in Geosiphon pyriforme (Kützing) F. v. Wettstein, an endosymbiotic association of fungus and cyanobacterium. Planta 185 (1991), 311-315

Kluge, M., Mollenhauer, D., and Mollenhauer, R. - Geosiphon pyriforme (Kützing) von Wettstein, a promising system for studying endocyanoses. Progr. Bot. 55 (1993), in press.

Kluge, M., Mollenhauer, D., Mollenhauer, R., and Kape, R. -Geosiphon pyriforme, an endosymbiotic consortium of a fungus and a cyanobacterium (Nostoc), fixes nitrogen. Bot. Acta 105 (1992), 343-344.

Knapp, E. - Über Geosiphon pyriforme Fr. Wettst., eine intrazelluläre Pilz-Algen-Symbiose. Ber. Deutsch. Bot. Ges. 51 (1933), 210- 217.

Ligrone, R. - Ultrastructure of a fungal endophyte in Phaeoceros laevis (L.) Prosc. (Anthocerophyta). Bot. Gaz. 149 (1988), 92-100.

Ligrone, R. and Lopes, C. - Cytology and development of a mycorrhiza-like infection in the gametophyte of Conocephalum conicum (L.) Dum. (Marchantiales, Hepatophyta). New Phytol. 111 (1989), $423-433$

Livolant, F., Giraud, M. M., and Bouligand, Y. - A goniometric effect observed in sections of twisted fibrous materials. Biol. Cell. 31 (1978), 159-168.

Macdonald, R. M. and Chandler, M. R. - Bacterium-like organelles in the vesicular arbuscular mycorrhizal fungus Glomus caledonius. New Phytol. 89 (1981), 241-246.

Macdonald, R. M., Chandler, M. R., and Mosse, B. - The occurrence of bacterium-like organelles in vesicular-arbuscular mycorrhizal fungi. New Phytol. 90 (1982), 659-663.

Meier, R. and Charvat, I. - Germination of Glomus mosseae spores: procedure and ultrastructural analysis. Int. J. Plant Sci. 153 (1992), 541-549.

Mollenhauer, D. - Weitere Untersuchungen an Geosiphon pyriforme einer Lebensgemeinschaft von Pilz und Blaualge. Natur u. Museum 118 (1988), 289-309.

Mollenhauer, D. - Geosiphon pyriforme. In: Reisser, W., ed., Algae and Symbiosis: Plants, Animals, Fungi, Viruses, Interactions Explored. pp. 339-351. Biopress Limited, Bristol, 1992.

Mollenhauer, D. and Mollenhauer, R. - Geosiphon cultures ahead. Endocyt. Cell Res. 5 (1988), 69-73.

Morton, J. B. - Taxonomy of VA mycorrhizal fungi: classification, nomenclature, and identification. Mycotaxon 32 (1988), 267-324.

Morton, J. B. - Evolutionary relationships among arbuscular mycorrhizal fungi in the Endogonaceae. Mycologiy 82 (1990), 192- 207.

Morton, J. B. and Benny, G. L. - Revised classification of arbuscular mycorrhizal fungi (Zygomycetes): A new order, Glomales, two new suborders, Glomineae and Gigasporineae, and two new families, Acaulosporaceae and Gigasporaceae, with an emendation of Glomaceae. Mycotaxon 37 (1990), 471-491.

Mosse, B. - Honey coloured endogone spores: I. Life history. Arch. Mikrobiol. 74 (1970a), 167-175.

Mosse, B. - Honey coloured endogone spores: II. Changes in fine structure during spore development. Arch. Mikrobiol. 74 (1970b), 129 145

Mosse, B. - Honey coloured endogone spores: III. Wall structure. Arch Mikrobiol. 74 (1970c), 146-159.

Mosse, B. - Ultrastructure of the spore wall in some VA mycorrhizal fungi. In: Gianinazzi-Pearson, V. and Gianinazzi, S., eds., Mycorrhizae: Physiology and Genetics. Proc. First. Europ. Symp. Mycorrhizae. pp. 615-620. CNRS-INRA, Dijon, July 1-5 1985, 1986.

Nemec, B. - Die Mycorrhiza einiger Lebermoose. Ber. Deutsch. Bot. Ges. 17 (1899), 311-317.

Parke, J. L. and Linderman, R. G. - Association of vesicular-arbuscular mycorrhizal fungi with the moss Funaria hygrometrica. Can. J. Bot. 58 (1980), 1898-1904.

Pocock, K. and Duckett, J. G. - A comparative ultrastructural analysis of the fungal endophytes in Cryptothallus mirabilis Malm. and other british thalloid hepatics. J. Bryol. 13 (1984), 227-233.

Protzenko, M. A. - The pea's mycorrhiza ultrastructure. Botan. Z.Akad. Nauk 59 (1974), 868-874.

Protzenko, M. A. - Microorganism in the hyphae of mycorrhizaforming fungus. Mikrobiologiya 44 (1975), 1121-1124.
Scannerini, S. and Bonfante-Fasolo, P. - Comparative ultrastructura analysis of mycorrhizal associations. Can. J. Bot. 61 (1982), 917 943.

Scannerini, S. and Bonfante-Fasolo, P. - Bacteria and bacteria-like objects in endomycorrhizal fungi (Glomaceae). In: L. Margulis and R. Fester, eds., Symbiosis as a Source of Evolutionary Innovation: Speciation and Morphogenesis. pp. 273-287. MIT Press, Cambridge, London, 1992.

Schmid, E. and Oberwinkler, F. - Mycorrhiza-like interaction between the achlorophyllous gametophyte of Lycopodium clavatum $\mathrm{L}$. and its fungal endophyte studied by light and electron microscopy. New Phytol. 124 (1993), 69-81.

Schnepf, E. - Zur Feinstruktur von Geosiphon pyriforme. - Ein Versuch zur Deutung cytoplasmatischer Membranen und Kompartimente. Arch. Mikrobiol. 49 (1964), 112-131.

Simon, L., Bousquet, J., Lévesque, R. C., and Lalonde, M. - Origin and diversification of endomycorrhizal fungi and coincidence with vascular land plants. Nature 363 (1993), 67-69.

Simon, L., Lalonde, M., and Bruns, T. - Specific amplification of $18 \mathrm{~S}$ fungal ribosomal genes from vesicular-arbuscular endomycorrhizal fungi colonising roots. Appl. Environ. Microbiol. 58 (1992), 291-295.

Spurr, A. R. - A low-viscosity epoxy resin embedding medium for electron microscopy. J. Ultrastruct. Res. 26 (1969), 31-43.

Stahl, M. - Die Mycorrhiza der Lebermoose mit besonderer Berücksichtigung der thallösen Formen. Planta 37 (1949), 103-148.

Sward, R. J. - The structure of the spores of Gigaspora margarita. I. The dormant spore. New Phytol. 87 (1981a), 761-768.

Sward, R. J. - The structure of the spores of Gigaspora margarita. II Changes accompanying germination. New Phytol. 88 (1981b), $661-666$.

Sward, R. J. - The structure of the spores of Gigaspora margarita. III Germ-tube emergence and growth. New Phytol. 88 (1981c), $667-$ 673.

Trappe, J. M. - Synoptic keys to the genera and species of zygomycetous mycorrhizal fungi. Phytopathology 72 (1982), 1102- 1108.

Vian, B., Roland, J.-C., and Reis, D. - Primary cell wall texture and its relation to surface expansion. Int. J. Plant Sci. 154 (1993), 1-9.

Walker, C. - Taxonomic concepts in the Endogonaceae: spore wall characteristics in species descriptions. Mycotaxon 18 (1983), 443 455 .

Walker, C. - Current concepts in the taxonomy of the Endogonaceae. In: Sylvia, D. M., Hung, L. L., and Graham, J. H., eds., Mycorrhizae in the Next Decade, Practical Applications and Research Priorities. pp. 300-302. IFAS, University of Florida, Gainesville, 1987.

Weijmann, A. C. M. and Meuzelaar, H. L. C. - Biochemical contributions to the taxonomic status of the Endogonaceae. Can. J. Bot. 57 (1979), 284-291.

Wettstein, F. von - Geosiphon Fr. Wettst., eine neue interessante Siphonee. Österr. Bot. Z. 65 (1915), 145-156.

Wyss, P. and Bonfante, P. - Amplification of genomic DNA of arbuscular-mycorrhizal (AM) fungi by PCR using short arbitrary primers. Mycol. Res. 97 (1993), in press.

\section{A. Schüßler}

Institut für Botanik

der Technischen Hochschule Darmstadt

Schnittspahnstraße 10

D-64287 Darmstadt

Federal Republic of Germany 